\title{
La Psicolingüística y el aprendizaje del inglés en los adultos
}

\section{Psycholinguistics and seniors' EFL}

\author{
EULALIO FERNÁNDEZ SÁNCHEZ \\ ff1fesae@uco.es \\ Universidad de Córdoba
}

Fecha de recepción: 26 de agosto de 2013

Fecha de aceptación: 30 de septiembre de 2013

\begin{abstract}
This contribution presents the epistemological underpinnings of the methodology that has been used in the University of Córdoba (Spain) for teaching English as a foreign language to seniors (over 50) for the last four years. The method is based on the scientific evidence provided by the most recent insight achieved within psycholinguistics and the cognitive theory of learning. The results of this experience reveal that this method specially favors EFL processes by reducing the social distance of seniors towards L2 by means of a direct access to the explicit and declarative knowledge of the target language.
\end{abstract}

Key words: EFL. Seniors. Psycholinguistics. Cognitivism.

Resumen: Esta contribución presenta los presupuestos epistemológicos de la metodología usada en la Universidad de Córdoba (España) para enseñar inglés como lengua extranjera a los estudiantes senior (más de 50 años) durante los últimos cuatro años. El método se basa en la evidencia científica proporcionada por los más recientes avances alcanzados en el ámbito de la psicolingüística y la teoría cognitiva del aprendizaje. Los resultados de esta experiencia revelan que este método favorece especialmente los procesos de aprendizaje del inglés como lengua extranjera mediante la reducción de la distancia social de los aprendices adultos hacia la L2 a través del acceso directo al conocimiento explícito y declarativo de la lengua destino.

Palabras clave: EFL. Adultos. Psicolingüística. Cognitivismo.

\section{Introduction}

On the basis of the insight provided by psycholinguistics and cognitive science in recent decades, language acquisition is conceived of as the implementation of an instinct that makes human being a species and different from the rest of animals. The realization of this instinct takes place along a critical period in which the brain has the neural-physiological ductility and potentiality required to trigger the language acquisition device and eventually acquire the mother tongue. Notwithstanding, the end of this critical period does not imply that human beings cannot learn further languages. However, although the acquisition of a second 
language and the acquisition of the mother tongue are analogous processes, they are absolutely distinct from a psycholinguistic and cognitive point of view.

In the particular case of teaching English as a FL to seniors (from the age of 50 onwards), language learning is subject to the rules and principles governing any process of acquisition of a cognitive skill. In more concrete terms, the acquisition of a cognitive skill consists of the apprehension of knowledge which must be accommodated in memory. When teaching English as a FL, seniors go through three different stages (cognitive, associative and autonomous), along which they transform the declarative knowledge they have been presented with into the procedural knowledge which will eventually enable them to use English in a creative and spontaneous manner. Throughout this process, the senior learner is fully aware of the stages and plays a very active role by taking profit of the cognitive, metacognitive and socio-affective they have in order to process, learn, keep and store the new knowledge most effectively.

In this paper, we intend to present the results of a project carried out in the University of Cordoba (Spain) in the framework of a course of EFL teaching to seniors for four academic years. The methodology and materials used in this course are based on the epistemological underpinnings described below.

\section{Epistemological underpinnings}

The series Inglés Instrumental para Adultos (Instrumental English for seniors) (Fernández \& Torralbo, 2010, 2011, 2012) is the result of the research carried out recently by the group Lingüística Cognitiva y Funcional: Teoría y Aplicaciones (Cognitive and Functional Linguistics: Theory and Applications) funded by the regional Government of Andalucía, Spain. One of the research lines of this group has been the analysis of SLA processes from the theoretical framework posed by the cognitive paradigm. As a result of this research, it has been possible to gain insight into the understanding and comprehension of the role played by aspects like L1, translation and learning strategies in SLA processes by several groups of individuals such as blind, deaf, early learners, special educational needs students and seniors.

The epistemological underpinnings of this methodology are derived from a cognitive consideration of language, according to which language is regarded, on the one hand, as an instinctive faculty of human beings resulting into the development of a rich and productive means of communication, and on the other hand, as a systemic code consisting of a hierarchically-organized and layered system of signs. From this cognitive perspective, a number of theoretical assumptions arise, like the relevance of the learning subject, the usage of conceptual schemata, the active role of subject in cognitive processes, the role of cognitive abilities and the limitations and singularities of the human cognitive system.

The multi-disciplinary and inter-disciplinary nature of the cognitive paradigm (Gardner, 1988) does not only affect the origin of the contributions, but also impacts upon the light that new perspectives can shed upon the same object of study. In this 
context a bio-linguistic approach to the nature of language emerges, and by extension to the very nature of the linguistic sign, from positions proximate to the precepts of biology and to psycholinguistics. According to Nubiola (2009: 8), "the viewpoint of those who think that language appeared by natural selection as an adaptation for communication and that from this grew our mental life as a derivative product is persuasive".

Equally, Pinker and Bloom (1997) point out that "according to this hypothesis, to be intelligent is not - as many have assumed - to have a language, but rather to have a language is what makes one intelligent". However, Nubiola (2009: 9) clarifies that "It is worth adding straight away that not all aspects of intelligence are reducible to language, since there is clear proof of this both in the intelligent conduct of prelinguistic children and in the remarkable intellectual life of individuals lacking language".

One of the best examples of this type of study is given by the work of Antonio Damasio and in particular his last contribution (Damasio, 2010), in which he explains the manner in which neuronal connections lead to our mind and the awareness of it.

Therefore, in the line of cognitive studies of a psycho-biological nature, the search for the essence of human nature must pause to explore the analysis of the nature of language. Thus, Nubiola (2009: 8) affirms that "this strange capacity to unite and to relate disparate elements is exclusive to Homo sapiens, and it is perhaps this exclusivity which is the most incomprehensible aspect for many scientists". For this reason, it is the capacity to establish a relation between disparate elements through an element considered to be common and capable of leading to this relation or union which points to the distinction. It is something which animals could never attain, which explains why "the tireless attempts to teach sign language to chimpanzees and other higher primates clearly demonstrate that in their greatest communicative activity they do not manage to reach this triadic structure (object / flower, sign / the flower, and the agent conscious of its articulation), rather they do not pass beyond the stage of the pre-linguistic babbling of an infant of only a few months calling for its mother's milk" (Nubiola, 2009: 11).

In this way the psycho-bio-linguistic approach attempts to fill the gap in our scientific culture in which we pass from biology to linguistics without explaining this leap, which even in evolutionary terms appears so extraordinary (Percy, 1996). And thus, it is that towards the end of the 20th century human beings appear as creatures divided between biology and linguistics without a sufficiently comprehensible global explanation being proffered. The human being cannot be understood without intentional communicative strategies, that is, one cannot talk to someone without pondering what the other is thinking. Even silence is communicative. From its birth the human baby is programmed for communication (Aguado, 1995). For this reason, the appearance of language can only be explained if it is considered a shared instrument of communication. 
In cognitive terms, language is defined as a system of communication based on conventionalized knowledge. The interrelationship between language and our cognitive system is revealed on the twofold nature of cognitively-oriented linguistic studies. In this way, the insight gained in cognitive disciplines such as psycholinguistics and neuroscience can be applied onto linguistic analysis, and viceversa, the insight gained in linguistic studies can enlighten cognitive processes. In Langacker's words (1987, p. 12), “language turns out much more natural as we know more aspects of human cognitive capacities". So, language and cognitive abilities of human beings make up an interconnected complex whose results can illuminate human cognition and the true nature of language.

The application of these epistemological underpinnings into the understanding of SLA processes requires a psycholinguistic approach. Psycholinguistics, born in the debate between competence and performance during the 50's, provides researchers with the methodology and insight required to make sense of the processes and subprocesses by means of which humans acquire and use language. Although psycholinguistics, in the last few decades, has permitted to comprehend such linguistic processes as production, comprehension and acquisition, notwithstanding, there have been rare attempts to apply the psycholinguistic methodology into the understanding of second and foreign language processes, both learning and teaching. Therefore, the main contribution of the material detailed below is the implementation of psycholinguistic methodology and principles into foreign language teaching to seniors within a cognitive-oriented approach to SLA processes.

\section{Teaching foreign languages to adults on a psycholinguistic and cognitive basis}

As stated above, on the evidence recently provided by psycholinguistics and cognitive linguistics, language acquisition is conceived of as the realization of a biological instinct which defines and makes human beings a unique species and different from the rest of animals. The implementation of such an instinct (Pinker, 1997) takes place along the so-called critical period (Lenneber, 1967), along which the brain enjoys the required neuro-physiological ductility and flexibility so as to trigger the LAD (language acquisition device) responsible of the acquisition of the principles and parameters of a linguistic sign, resulting into the eventual acquisition of the mother tongue or first language. Once the critical period is over, the brain has already accomplished a biological task and loses the neuro-physiological capabilities which make it possible for humans to acquire language in a natural framework.

However, the end of the critical period does not prevent humans from acquiring further languages alongside with the mother tongue. But it would be a sound mistake to consider that those processes are similar, in spite of having the same target, that is, communication via an oral linguistic system. In cognitive terms, FLL (foreign language learning) is instead similar to the acquisition and learning of any other cognitive skill. In other words, FLL is governed by the rules and strategies which are 
present in the acquisition of any other cognitive skill throughout life. Thus, the exposure to the intended skill, continuous practice, the psycho-cognitive singularities of learners, the influence of socio-cultural factors, the individual learning styles and previous experience will definitely determine the acquisition and development of a particular cognitive skill.

The comprehensive consideration of all these factors enables us to approach FLL by seniors in terms of the acquisition of a complex cognitive skill. Therefore, FLL is based on a global model of learning cognitive abilities (Fernández, 2013). This model was first applied during the mid-eighties to specific and concrete aspects of the learning process. The innovative element of our approach consists of the usage of this theoretical construct as the basis for the particular design of a method to a FL to seniors.

So, according to this perspective the acquisition of any cognitive skill is based on knowledge storage and management. The knowledge involved in learning processes has a twofold nature: declarative (knowing about) and procedural (knowing how to) (Anderson, 1983). The key question of our cognitive approach is how to go through the psycho-linguistic process in order to transform the declarative knowledge subject to rules into an autonomous proceduralized skill.

This process consists of three stages:

1. Cognitive stage: During this stage, learners are instructed how to accomplish the task, they watch other people doing it and try hard to study it by themselves. Learners at this stage are fully-aware and conscious of the process. The knowledge achieved is mainly declarative and can be presented explicitly and verbalized by learners. However, it is not sufficient for fluent communication since performance at this stage is still very deliberate and full of mistakes

2. Associative stage: Along this stage the errors resulting from the declarative representation of knowledge are detected and progressively amended, so that the connections and associations between the components of knowledge are strengthened and reinforced. Declarative knowledge increasingly becomes proceduralized, although performance remains non-natural and artificial.

3. Autonomous stage: When learners get to this final stage, performance turns out automatic and lack of mistakes lead to successful communication. The skill is implemented without effort and requires less awareness and working memory, resulting into a progressive improvement of performance.

The existence of these three stages is based on the assumption that learners get the rules underlying the realization of a complex skill prior to the autonomous and natural performance (Gagne, 1985). Since it is a fully conscious and aware process, the active role of learners will have a significant relevance. It will result into the usage and exploitation of the learning strategies (O’Malley \& Chamot, 1996) which are suitable for achieving the desired goal. 
Those strategies mainly consist of behaviors and thoughts that learners may use for understanding, apprehending and storing new information. By means of these strategies, learners improve their management of information and knowledge. Thus, a FL teaching method based on this cognitive theory of learning must explain for the cognitive processes involved in the comprehension and storage of knowledge, and for the transformation of that declarative information into the procedural knowledge required for the automatic understanding and production of a second language. In this way, our methodological proposal is based on the appropriate usage of the metacognitive, cognitive and socio-affective strategies by seniors in the psycholinguistic process of learning English as a FL.

\section{Focus on the materials used for teaching EFL to seniors}

The material that we have developed for implementing the theoretical approach described above has been designed so that learners can get the linguistic contents and skills included in the different levels of competence according to CEFL (Common European Framework for Languages: Learning, Teaching and Assessment). So far, our research group has already edited the textbooks corresponding to the levels A1, A2 and B1. It is a teaching tool intended for a formal academic setting. Through the contents, activities and resources included in this textbook alongside with teacher's instruction, seniors are likely to activate the metacognitive, cognitive and socio-affective strategies that can lead them into the intended mastery of the FL skills corresponding with each particular level.

The implementation of the theoretical principles outlined above into our teaching materials has led us to arrange the textbook in three basic modules. These modules are related to the stages that any learning process consists of: cognitive, associative and autonomous.

a) Cognitive module: it is devoted to the elicitation and explicit introduction of linguistic contents (lexical, phonological and grammatical). The apprehension of the declarative knowledge is aided by making continuous reference to $\mathrm{L} 1$, which will avoid interference and take advantage of previous knowledge, resulting into a more efficient usage of cognitive and meta-cognitive strategies, apart from reducing the social distance that seniors are likely to experience when introduced into a foreign language for the first time. 


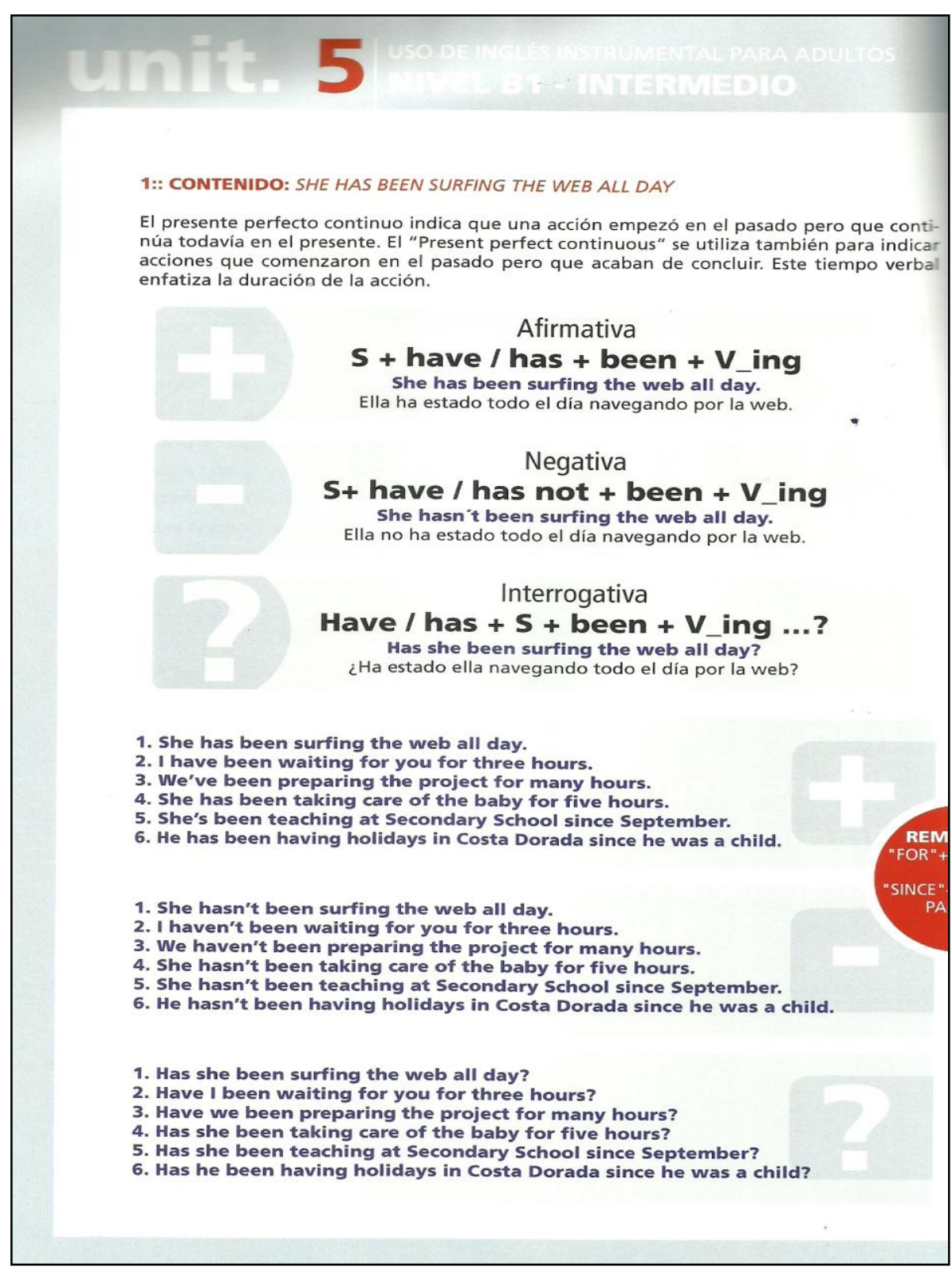

Figure 1. Textbook Instrumental English for seniors (Unit 5, p. 45) 
b) Associative module: it includes a list of controlled activities and drills. Learners are intended to set up the associations between the linguistic contents presented in a declarative and explicit manner and the linguistic skills that can be achieved by using those contents.

\section{4:: PRÁCTICA GUIADA}

$\mathbf{1}^{\text {st }}$ Complete the sentences with the right verb tense (Present perfect progressive):

1. He his car for twenty minutes. (To wash)

2. They TV for ten minutes. (To watch)

3. You a novel for five minutes. (To read)

4. We in Burgos since 2012. (To live)

5. I the report for two hours. (to prepare)

$2^{\text {nd }}$ Turn the following sentences into negative:

1. I have been preparing the project for four hours.

2. You have been writing emails for forty minutes.

3. He has been boiling the mushrooms for twenty minutes.

4. She has been cleaning the bathroom for half an hour.

5. They have been studying English for thirty minutes.

$3^{\text {rd }}$ Change the following sentences into question:

1. You have been preparing the new recipe for one hour.

2. He has been cooking the pork with carrots for fifty minutes.

Figure 2. Textbook Instrumental English for seniors (Unit 5, p. 36) 
c) Autonomous module: it involves a serious of free practice activities by means of which learners can find a more intensive opportunity to transform declarative and regulated knowledge into the implicit and procedural knowledge required for natural and fluent communication.

\section{PRÁCTICA \\ LIBRE}

A Will there be a pay rise next year?

B Yes, there will be a pay rise next year.

No, there won't be a pay rise next year.

A Will there be many clients for the new product?

B Yes, there vill be many clients for the new product.

No, there won't be many clients for the new product.

\section{5}

A Has Bob been surfing the web all day?

$B \quad Y e s, B o b$ has been surfing the web all day.

No, Bob hasn't been surfing the web all day.

A Has William himself been cooking all the morning?

B Yes, he has been cooking all the morning. No, he hasn't been cooking all the morning

A Are Charles and Patricia talking to each other?

B Yes, they are. / No, they aren't.

A Can one out of every two Italian teachers speak English?

B Yes, they can. / No, they cannot.

A Did seven out of every ten people support the new law?

B Yes, they did. / No, they didn't.

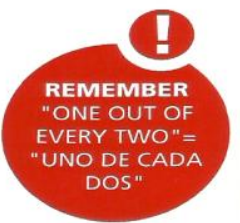

Figure 3. Textbook Instrumental English for seniors (Free practice section, p. 236)

The cognitive and associative modules have been arranged in fifteen units dealing with the topics and skills included in each level of competence of CEFL (A1, A2, B1). As for the autonomous module, it is developed through a series of free activities by means of which seniors are presented with the input and practice required for getting to the expected proficiency on written and oral skills. 


\section{Conclusion}

It can be concluded that the combination of the methodological and epistemological assumptions provided by psycholinguistics and cognitive theory of learning provide SLA researchers with a profitable platform in order to design FL teaching materials which are especially coherent with the internal (psychocognitive) processes of seniors and which, in turn, make it possible for this group of learners to take advantage of their cognitive, meta-cognitive and socio-affective strategies. So far, these materials have proved to be mainly useful for reducing the social distance towards L2 experienced by seniors and for taking advantage of the learning capabilities of this group of learners. No doubt, it can be a serious contribution to the active ageing of a very significant group of individuals in our contemporary society.

\section{References}

Aguado, G., El desarrollo del lenguaje de 0 a 3 años. Bases para un desarrollo curricular en la educación infantil. Madrid: Editorial CEPE (Ciencias de la Educación Preescolar y Especial), 1995.

ANDERSON, J. R., The architecture of cognition. Cambridge, Mass.: HUP, 1983.

CHAmot, A. and J. O’MALLEY, "The Cognitive Academic Language Learning Approach: A model for linguistically diverse classrooms", in The Elementary School Journal, 96. (3), 1986, pp. 258-273.

DAMASIO, A., Y el cerebro creó al hombre. Barcelona: Ed. Paidós, 2010.

FERnÁndeZ, E. \& TORRALBO, J., Inglés instrumental para adulto - Nivel A1. Granada: Grupo Editorial Universitario, 2010. , Inglés instrumental para adultos - Nivel A2. Granada: Grupo Editorial Universitario, 2011.

, Inglés instrumental para adultos - Nivel B1. Córdoba: Editorial Don Folio, 2012.

FERNÁNDEZ, E., La psicolingüística y el aprendizaje de lenguas extranjeras. Córdoba: Servicio de Publicaciones de la Universidad de Córdoba, 2013.

GAGNÉ, E., The cognitive psychology of school learning. Boston, Mass.: Little, Brown, 1985.

GARDNER, H., La nueva ciencia de la mente. Historia de la revolución cognitiva, Barcelona, Ediciones Paidós, 1988.

LANGACKER, R., Foundations of cognitive grammar. Standford: SUP 1987.

LENNEBERG, E. H., Biological Foundations of Language. New York: Wiley, 1967.

NuBIOLA, J., La investigación filosófica sobre el origen del lenguaje. Pensamiento y Cultura, 2009.

PERCY, W., "La criatura dividida”. In: Anuario Filosófico, 29, p 1146-1148, 1996.

PINKER, S., El instinto del lenguaje. Madrid: Alianza, 1994.

Pinker, S. \& Bloom, P., Natural Language and Natural Selection. Behavioral and Brain Sciences, 13, 1997, p. 585-642 